\title{
Optimasi Formula Tablet Floating Nifedipin Menggunakan HPMC K15M, PVP K-30 dan Avicel PH 102 dengan Metode Simplex Lattice Design
}

\section{Floating Nifedipin Tablet Foermula Optimization using HPMC HPMC K15M, PVP K-30 and Avicel PH 102 with Simplex Lattice Design Method}

\author{
Siti Aisiyah ${ }^{1)}$, Achmad Fudholi ${ }^{2}$, Abdul Rohman ${ }^{3)}$ \\ 1,2,3) Fakultas Farmasi Universitas Gadjah Mada, Yogyakarta \\ 1, 2, 3) Yogyakarta, mynanda.ais@gmail.com
}

\section{Intisari}

Nifedipin merupakan obat dengan kelarutan kecil dalam air sehingga kelarutan nifedipin perlu ditingkatkan dengan penambahan PVP K-30. Penelitian ini bertujuan untuk mengetahui pengaruh HPMC K15M, PVP K-30 terhadap pelepasan nifedipin, dan Avicel PH 102 terhadap floating lag time tablet floating nifedipin, serta untuk mengetahui proporsi masing-masing bahan untuk membuat formula optimum tablet floating nifedipin.

Penelitian dilakukan dengan metode simplex lattice design (SLD) dengan 3 komponen yaitu HPMC K15M, PVP K-30 dan Avicel PH 102 sehingga diperoleh 14 formula. Parameter optimasi terdiri dari daya serap tablet, floating lag time, $C_{360}$ dan $D_{360}$. Keempat parameter dianalisis menggunakan software Desain Expert 7.1.3 untuk menentukan formula optimum. Formula optimum diperoleh dengan menentukan target yang diinginkan untuk masing-masing parameter. Daya serap dipilih target maksimum, floating lag time dipilih target minimum, $\mathrm{C}_{360}$ ditarget pada angka 54, dan $\mathrm{DE}_{360}$ ditarget pada angka 40.

HPMC K15M pada konsentrasi paling tinggi berpengaruh pada pelepasan nifedipin paling kecil, PVP K-30 pada konsentrasi paling tinggi berpengaruh pada pelepasan nifedipin paling besar, sedangkan Avicel PH 102 pada konsentrasi paling tinggi berpengaruh kecil terhadap penurunan floating lag time tablet floating nifedipin. Proporsi formula optimum HPMC K15M 80 mg, PVP K-30 97 mg dan Avicel PH $10245 \mathrm{mg}$. Daya serap tablet, $\mathrm{C}_{360}$ dan $\mathrm{DE}_{360}$ memberikan hasil tidak berbeda signifikan, floating lag time memberikan hasil berbeda signifikan terhadap hasil prediksi software. Kinetika pelepasan semua formula mengikuti orde 1 , menunjukkan bahwa pelepasan obat terjadi melalui mekanisme difusi.

Kata kunci: nifedipin, tablet floating, HPMC K15M, PVP K-30, Avicel PH 102.

\footnotetext{
Abstract

Nifedipine is a drug with a small solubility in water, a consequence, in order to obtain the desired drug release, the solubility of nifedipine should be increased by the addition of PVPK-30.This study was aimed to know the effect of HPMC K15M, PVP K-30 on the release of nifedipin, and Avicel $\mathrm{PH} 102$ on the floating lag time of nifedipin
} 
floating tablet, and to find out the proportion of each ingredient to produce the optimum formula of nifedipin floating tablet.

The study was conducted using Simplex Lattice Design (SLD) with 3 components i.e. HPMC K15M, PVPK-30 andAvicel PH 102 in order to obtain 14 formulas. The optimization parameter consists of absorption tablet, floating lagtime, $\mathrm{C}_{360}$ and $\mathrm{DE}_{360}$. The four parameters were analyzed using Design Expert7.1.3 software to determine the optimum formula. The optimum formula was obtained by determining the desired target for each parameter. The absorption was selected in maximum target, floating lag time was selected in minimum target, $\mathrm{C}_{360}$ targeted at number 54 and $\mathrm{DE}_{360}$ targeted at number 40 .

HPMC K15M at the highest concentration affected the smallest release of nifedipin, the highest PVP K-30 concentration affected the most of nifedipin release, where as high concentration Avicel PH 102 had a small affected reduce in floating lag time of nifedipin floating tablet. The composition of the optimum formula is as follows: $80 \mathrm{mg}$ HPMC K15M, 97mg PVPK-30 and 45mg Avicel PH 102. The results of tablet absorption, $\mathrm{C}_{360}$ and $\mathrm{DE}_{360}$ did not differ significantly; floating lag time gave significantly different results to obtain from software. The release kinetics of all formulas fit order 1 , which indicated that the drug release occurred through a diffusion mechanism.

Keywords: nifedipin, floating tablet, HPMC K15M, PVP K-30, Avicel PH 102

\section{Pendahuluan}

Nifedipin merupakan suatu antagonis kanal kalsium dihidropiridin yang digunakan untuk pengobatan penyakit kardiovaskuler, hipertensi dan anginapektoris. Nifedipin merupakan obat dengan kelarutan dalam air yang kecil dan termasuk dalam Biopharmacentic Classification System (BCS) kelas 2 (Lalitha dan Lakshmi, 2011), sehingga untuk mendapatkan pelepasan obat yang diinginkan, kelarutan nifedipin perlu ditingkatkan dengan penambahan PVP K-30 (Rhodes, 1992). Nifedipin diabsorpsi dengan cepat dan hampir sempurna $(90 \%)$ dalam lambung (Hardjono, 2000).Setelah pemberian oral, konsentrasi puncak nifedipin dalam darah terjadi setelah 30 sampai 120 menit dengan waktu paruh antara 2-5 jam (Sweetman, 2009), sehingga lebih efektif dibuat dalam sediaan gastroretentive.

Nifedipin dengan karakteristik seperti di atas, dapat dikembangkan dalam formulasi tablet floating dengan matriks HPMC yang bersifat hidrofilik. HPMC dapat membentuk lapisan hidrogel yang kental di sekeliling sediaan setelah kontak dengan cairan medium pelarut. Gel ini merupakan penghalang fisik lepasnya obat dari matriks. Proses pelepasan obat dari matrik penghalang dapat terjadi dengan mekanisme erosi dan difusi. Avicel PH 102 sebagai bahan pengisi berperan pada penurunan kerapatan sistem floating, sehingga bersama dengan HPMC berperan dalam proses pengapungan tablet (Daharwal, 2007).

Beberapa hasil penelitian menyebutkan bahwa PVP dapat meningkatkan kelarutan nifedipin. Banyaknya PVP K-30 yang digunakan untuk meningkatkan kelarutan nifedipin adalah 10-90 \% berat nifedipin (Rhodes, 1992). Perbandingan nifedipin dan PVP K-30 yang dapat memberikan kelarutan optimum adalah 1:2 (Nurjayanti, 2008).

Metode Simplex Lattice Design(SLD) merupakan salah satu teknik optimasi formula untuk mendapatkan daerah yang optimum. Teknik ini terutama sesuai untuk prosedur optimasi formula yang mana jumlah total dari bahan yang berbeda adalah konstan (Bolton dan Bon, 2004). Pemilihan metode SLD didasarkan pada optimasi campuran bahan dengan variasi konsentrasi yang berbeda dan berat totalnya adalah konstan. Optimasi formula diperlukan untuk mengetahui proporsi campuran HPMC K15M, PVP K-30 dan Avicel PH 102 yang 
optimum sehingga mendapatkan sediaan tablet floating nifedipin yang optimum

\section{Metode Penelitian}

Bahan:

Bahan yang digunakan dalam penelitian ini adalah nifedipin micronized (dymach pharma, India), PVP K30 (Nanhang Industrial CO, .LTD, China), HPMC K15M (Shin Etsu, Jepang), magnesium stearat (Faci Asia Pte Ltd., Singapura), Avicel PH 102 (Mingtai Chemical Co.Ltd, Taiwan), natrium klorida (Bratachem), natrium lauril sulfat (Bratachem), serta HCL p.a. (Merck). Semua bahan yang digunakan adalah kualitas farmasi.

Alat:

Cube mixer (Erweka AR 400), Hardness tester (vanguard model YD-1), friabilator tester (Pharmec), mesin tablet single punch (Rieckermann Korsch Berlin), disintegration tester (Erweka G.m.b.h Type Z.T-2), alat uji disolusi (dissolution tester DT 606, Erweka), neraca analitik dengan kepekaan 0,1 mg (Inaba Seissakusho LTD, Tokyo, Japan), spektrofotometer UV-Vis (Genesys 10UV Scanning, Thermo Elektron Scientifik Instrument Corporatoin, USA), flowability tester (Erweka, Jerman), alat uji pengetapan
(Erweka, Jerman), stopwatch (Heuer) dan alatalat gelas yang lazim digunakan.

\section{Jalannya Penelitian}

Tablet floating nifedipin diformulasi dengan sistem effervescent, menggunakan HPMC K15M sebagai polimer, PVP K-30 sebagai solubilizer, natrium bikarbonat dan asam sitrat sebagai komponen effervescent, magnesium stearat dan talk sebagai pelicin, serta Avicel PH 102 sebagai pengisi. Rancangan Formula tablet floating nifedipin yang akan dibuat dalam penelitian dapat dilihat pada Tabel 1.

Tablet floating nifedipin dibuat dengan berat $300 \mathrm{mg}$. Nilai sebenarnya dari angka 0 dan 1 dapat dilihat pada Tabel 2 dan Rancangan formula untuk dioptimasi dengan metode Simplex Lattice Design (SLD) dapat dilihat pada Tabel 3

Pembuatan tablet floating nifedipin menggunakan metode granulasi kering dalam ruangan dengan kelembaban rendah $(\mathrm{RH}<$ 40\%). Massa tablet diuji kecepatan alir, sudut diam dan kompresibilitas. Tablet yang telah dicetak diuji keseragaman bobot, keseragaman kandungan, kekerasan, kerapuhan, daya serap, floating lag time, durasi floating dan uji disolusi.

Tabel 1. Rancangan Formula Tablet Floating Nifedipin

\begin{tabular}{lc}
\hline \multicolumn{1}{c}{ Bahan } & Jumlah \\
\hline Nifedipin & $40 \mathrm{mg}$ \\
HPMC K15M & $0-1$ bagian \\
PVP K-30 & $0-1$ bagian \\
Avicel PH 102 & $0-1$ bagian \\
Natrium & $18,2 \mathrm{mg}$ \\
bikarbonat & \\
Asam sitrat & $13,8 \mathrm{mg}$ \\
Magnesium Stearat & $3 \mathrm{mg}$ \\
Talk & $3 \mathrm{mg}$ \\
\hline
\end{tabular}

Tabel 2. Nilai sebenarnya dari angka 0 dan 1

\begin{tabular}{rrrr}
\hline Angka & HPMC K15M (mg) & PVP K-30 (mg) & Avicel PH 102 (mg) \\
\hline 0 & 80 & 40 & 42 \\
1 & 140 & 100 & 102 \\
\hline
\end{tabular}


Tabel 3. Rancangan Formula untuk dioptimasi dengan metode SLD

\begin{tabular}{ccccc}
\hline Std & Formula & $\begin{array}{c}\text { HPMC K15M } \\
(\mathrm{mg})\end{array}$ & $\begin{array}{c}\text { PVP K-30 } \\
(\mathrm{mg})\end{array}$ & $\begin{array}{c}\text { AVICELPH 102 } \\
(\mathrm{mg})\end{array}$ \\
\hline 8 & 1 & 90 & 80 & 52 \\
11 & 2 & 140 & 40 & 42 \\
9 & 3 & 90 & 50 & 82 \\
3 & 4 & 110 & 40 & 72 \\
2 & 5 & 110 & 70 & 42 \\
10 & 6 & 100 & 60 & 62 \\
13 & 7 & 80 & 40 & 102 \\
1 & 8 & 140 & 40 & 42 \\
12 & 9 & 80 & 100 & 42 \\
6 & 10 & 80 & 40 & 52 \\
7 & 11 & 120 & 50 & 42 \\
14 & 12 & 110 & 70 & 72 \\
5 & 13 & 80 & 70 & 42 \\
4 & 14 & 80 & 100 & \\
\hline
\end{tabular}

Uji mutu fisik massa tablet

\section{a. Penentuan kecepatan alir}

Ditimbang dengan seksama $100 \mathrm{~g}$ massa tablet lalu dimasukan di dalam corong. Massa tablet dibiarkan mengalir melewati corong. Waktu yang diperlukan seluruh massa tablet melalui corong menunjukkan waktu alir dan dicatat. Kecepatan alir dinyatakan sebagai jumlah massa tablet yang melalui corong per detik (Siregar dan Wikarsa, 2010).

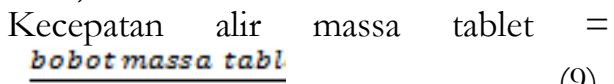

waktu alir

\section{b. Penentuan Sudut Diam}

Massa tabletyang membentuk kerucut pada penentuan kecepatan alir diatas diukur diameter dan tingginya, kemudian sudut diam dihitung menggunakan persamaan berikut (Siregar dan Wikarsa, 2010):

$\operatorname{Tan} \theta=\mathrm{h} / \mathrm{r}$

Keterangan:

$$
\begin{array}{ll}
\theta & : \text { sudut diam } \\
\mathrm{h} & : \text { tinggi kerucut } \\
\mathrm{r} & : \text { jari-jari kerucut }
\end{array}
$$

c. Penentuan persentase kompresibilitas Massa tablet dimasukkan dalam gelas ukur $100 \mathrm{~mL}$ (volume bulk), kemudian dilakukan penghentakan dengan motorized tappingdevice selama 5 menit dan diamati volume akhir massa tablet (volume tapped), lalu ditimbang untuk mengetahui beratnya. Persentase kompresibilitas dapat dihitung dengan persamaan:

$\%$ kompresibilitas $=\frac{\rho_{\text {tapped }}-\rho_{\text {bulk }}}{\rho_{\text {tapped }}} \times 100 \%$

Keterangan:

$$
\begin{array}{lll}
\rho_{\text {tappec }} & : & \text { setelah pengetapan } \\
\rho_{\text {bul }} & : & \text { sebelum pengetapan }
\end{array}
$$

\section{Uji mutu fisik tablet}

Uji mutu fisik tablet dilakukan dengan melakukan penentuan serangkaian parameter yakni uji keseragaman bobot, uji keseragaman kandungan, uji keseragaman ukuran tablet, uji kekerasan dan kerapuhan tablet, uji kemampuan floating, dan uji daya serap air.

\section{a. Uji keseragaman bobot}

Sebanyak 20 tablet ditimbang kemudian dihitung bobot rata-rata tiap tablet. Tablet ditimbang satu per satu pada neraca analitik. Tablet dikatakan memenuhi keseragaman bobot dengan syarat tidak boleh lebih dari 2 tablet yang menyimpang lebih dari bobot ratarata dari harga yang ditetapkan dalam kolom A $(7,5 \%)$ dan tidak boleh ada satu tablet pun yang bobotnya menyimpang lebih dari bobot rata-rata harga dalam kolom B (15\%), lalu dihitung nilai koefisien variasi (CV).

\section{b. Uji keseragaman kandungan}

$$
\text { Sepuluh tablet nifedipin }
$$

ditimbang satu persatu. Masing-masing tablet digerus, dilarutkan dalam metanol 
dengan perbandingan berat nifedipin dalam tablet adalah $1 \mathrm{mg}: 1 \mathrm{~mL}$ (Anonim, 2007), kemudian diencerkan dengan larutan $0,5 \%$ natrium lauril sulfat dalam larutan lambung buatan $\mathrm{pH}$ 1,2hingga volume 100,0 mL. Dari larutan tersebutdi pipet lagi $100 \mu \mathrm{L}$, lalu diencerkan dengan larutan 0,5\% natrium lauril sulfat dalam larutan lambung buatan $\mathrm{pH}$ 1,2hingga volume 10,0 mL, dan diukur serapannya dengan spektrofotometer UV-Vis pada panjang gelombang maksimum.

c. Uji keseragaman ukuran tablet

Diameter dan tebal tablet diukur menggunakan thikness tester dengan cara skala diatur pada posisi nol kemudian tablet diletakkan tegak lurus. Angka yang ditunjuk pada skala ini menunjukkan diameter tablet. Skala dikembalikan lagi pada posisi nol kemudian tablet diletakkan mendatar. Angka yang ditunjuk pada skala ini menunjukkan tebal tablet.

\section{d. Uji kekerasan tablet}

Tablet diletakkan pada ujung hardness tester kemudian skala diatur pada posisi nol. Ujung hardness tester yang laindiputar hingga tablet pecah. Angka yang ditunjukkan pada skala ini menunjukkan kekerasan tablet dalam satuan Kg. Percobaan dilakukan sebanyak 10 kali, dan dihitung nilai puratanya.

\section{e. Uji kerapuhan tablet}

Dua puluh tablet dibersihkan debunya kemudian ditimbang dalam neraca analitik dan dimasukkan ke dalam friabilator. Pengujian dilakukan selama empat menit atau sebanyak 100 putaran, kemudian tablet dibebasdebukan lagi. Pengurangan beratnya menunjukkan nilai kerapuhan tablet.

\section{f. Uji kemampuan floating}

Uji kemampuan floating dilakukan dengan cara memasukkan tablet ke dalam Beaker glass yang berisi larutan $0,5 \%$ natrium lauril sulfat dalam larutan lambung buatan $\mathrm{pH}$ 1,2 sebanyak 100 $\mathrm{mL}$, kemudian diamati sifat mengembang dan mengapung tablet secara visual (Shah dkk., 2009).

\section{g. Uji daya serap air}

Alat uji daya serap dihubungkan dengan timbangan elektrik yang di atasnya terdapat ampul. Posisinya diatur agar ampul dan timbangan tidak saling bersentuhan dengan kapiler yang disambung ke tempat bahan uji. Ampul diisi air hingga permukaannya rata dengan permukaan air pada tabung di alat uji daya serap (mengikuti prinsip tabung U). Kertas saring diletakkan pada tabung kemudian diatasnya diletakkan tempat atau holder untuk tablet yang akan diuji. Timbangan diatur pada skala nol dan tablet yang diuji ditimbang. Berkurangnya air yang terdapat di dalam ampul di atas timbangan menunjukkan jumlah air yang diserap oleh bahan, lalu dicatat setelah 15 menit.

\section{Uji disolusi tablet}

a. Pembuatan medium disolusi

Sebanyak 2 gram $\mathrm{NaCl}$ dilarutkan dalam akuades $500 \mathrm{~mL}$,ditambah $4 \mathrm{~mL}$ $\mathrm{HCl} 37 \%$ dan akuades sampai $1000 \mathrm{~mL}$, larutan mempunyai ini $\mathrm{pH} 1,2 \pm 0,05$ (Sinko dan Singh, 2011). Natrium lauril sulfat sebanyak 5 gram ditambahkan dalan cairan lambung diatas.

\section{b. Uji disolusi}

Berdasarkan USP XXXII (2009) uji disolusi tablet lepas lambat nifedipin menggunakan padle method tipe 2. Media disolusi adalah larutan $0,5 \%$ natrium lauril sulfat dalam larutan lambung buatan $\mathrm{pH}$ 1,2 sebanyak $900 \mathrm{~mL}$ dengan kecepatan pengadukan adalah $100 \mathrm{rpm}$ pada suhu $37^{\circ} \mathrm{C} \pm 0,5^{\circ} \mathrm{C}$. Pengujian dilakukan selama 6 jam dengan interval waktu $5,10,15,30,45,60,90,120,150$, 180, 210, 240, 300, dan 360 menit. Pengambilan larutan disolusi sebanyak $10,0 \mathrm{~mL}$ dan volume yang hilang diganti dengan media disolusi yang sama kemudian diukur absorbansinya pada panjang gelombang maksimum.

\section{Hasil dan Pembahasan}

Pembuatan tablet floating nifedipin menggunakan metode granulasi kering dengan alasan zat aktif tidak dapat mengalir dengan bebas dan bahan tambahan yang digunakan tidak mampu 
memperbaiki sifat alir serbuk. Metode untuk menguji sifat alir massa tablet dalam penelitian ini dengan menghitung kecepatan alir, sudut diam dan kompresibilitas (\%). Kecepatan alir yang baik adalah lebih dari $10 \mathrm{~g} /$ detik (Siregar dan Wikarsa, 2010), semakin kecil waktu alir yang dibutuhkan massa tablet untuk mengalir semakin baik kecepatan alirnya.
Sudut diam yang terbentuk dari semua formula lebih kecil dari $30^{\circ}$ menandakan bahwa massa tablet dapat mengalir dengan bebas. Persen kompresibilitas hasil penelitian dari semua formula kurang dari $25 \%$ bila dihubungkan dengan kemampuan mengalir masuk dalam kategori massa tablet yang mengalirnya cukup baik (Agoes, 2012).

Tabel 4. Hasil Uji Mutu Fisik Tablet

\begin{tabular}{|c|c|c|c|c|c|c|c|c|c|}
\hline \multirow{2}{*}{ Formula } & \multirow{2}{*}{$\begin{array}{c}\text { Bobot Tablet } \\
\text { (mg) }\end{array}$} & \multicolumn{2}{|c|}{ Ukuran tablet } & \multirow{2}{*}{$\begin{array}{c}\text { Kerapuhan } \\
(\%)\end{array}$} & \multirow{2}{*}{$\begin{array}{c}\text { Kekerasan } \\
\text { (kg) }\end{array}$} & \multicolumn{2}{|c|}{$\begin{array}{c}\text { Keseragaman } \\
\text { kandungan (\%) }\end{array}$} & \multirow{2}{*}{$\begin{array}{l}\text { Daya serap } \\
\text { (mg/mnt) }\end{array}$} & \multirow{2}{*}{$\begin{array}{l}\text { Floating } \\
\text { lag time } \\
\text { (menit) }\end{array}$} \\
\hline & & Diameter(mm) & Ketebalan(mm) & & & $\begin{array}{r}\text { Purata } \pm \\
\text { SD }\end{array}$ & CV & & \\
\hline 1 & $300,30 \pm 1,17$ & $10,024 \pm 0,005$ & $3,403 \pm 0,004$ & 0,064 & $7,28 \pm 0,59$ & $96,21 \pm 3,11$ & 3,23 & 5,687 & 2,21 \\
\hline 2 & $300,95 \pm 0,88$ & $10,022 \pm 0,004$ & $3,402 \pm 0,004$ & 0,067 & $8,14 \pm 0,38$ & $96,21 \pm 2,44$ & 2,54 & 5,813 & 35,12 \\
\hline 3 & $301,00 \pm 1,02$ & $10,022 \pm 0,004$ & $3,403 \pm 0,004$ & 0,066 & $7,86 \pm 0,47$ & $97,31 \pm 2,24$ & 2,30 & 5,913 & 5,14 \\
\hline 4 & $300,50 \pm 1,19$ & $10,038 \pm 0,004$ & $3,477 \pm 0,004$ & 0,050 & $7,80 \pm 0,39$ & $97,31 \pm 1,03$ & 1,04 & 5,967 & 7,21 \\
\hline 5 & $301,15 \pm 0,67$ & $10,048 \pm 0,004$ & $3,578 \pm 0,004$ & 0,066 & $8,46 \pm 0,25$ & $98,04 \pm 3,13$ & 3,19 & 5,407 & 4,50 \\
\hline 6 & $301,20 \pm 0,76$ & $10,023 \pm 0,004$ & $3,397 \pm 0,004$ & 0,065 & $8,10 \pm 0,47$ & $98,36 \pm 0,95$ & 0,97 & 5,613 & 5,12 \\
\hline 7 & $301,05 \pm 0,88$ & $10,022 \pm 0,004$ & $3,325 \pm 0,005$ & 0,050 & $7,28 \pm 0,36$ & $98,68 \pm 1,33$ & 1,35 & 5,593 & 7,55 \\
\hline 8 & $301,20 \pm 1,15$ & $10,022 \pm 0,004$ & $3,406 \pm 0,005$ & 0,066 & $8,24 \pm 0,42$ & $98,49 \pm 1,03$ & 1,05 & 5,627 & 30,15 \\
\hline 9 & $299,70 \pm 1,30$ & $10,043 \pm 0,004$ & $3,395 \pm 0,005$ & 0,050 & $8,19 \pm 0,23$ & $99,09 \pm 1,75$ & 1,77 & 6,400 & 1,04 \\
\hline 10 & $300,00 \pm 0,85$ & $10,022 \pm 0,004$ & $3,323 \pm 0,004$ & 0,067 & $7,44 \pm 0,32$ & $98,54 \pm 1,27$ & 1,29 & 5,793 & 5,13 \\
\hline 11 & $299,90 \pm 0,25$ & $10,040 \pm 0,004$ & $3,407 \pm 0,007$ & 0,065 & $7,89 \pm 0,52$ & $99,18 \pm 2,02$ & 2,04 & 5,750 & 5,14 \\
\hline 12 & $301,00 \pm 0,82$ & $10,050 \pm 0,004$ & $3,576 \pm 0,005$ & 0,065 & $8,39 \pm 0,33$ & $99,09 \pm 0,67$ & 0,67 & 5,420 & 4,15 \\
\hline 13 & $301,60 \pm 1,23$ & $10,043 \pm 0,004$ & $3,326 \pm 0,005$ & 0,082 & $7,56 \pm 0,48$ & $99,41 \pm 0,89$ & 0,89 & 5,840 & 3,30 \\
\hline 14 & $299,95 \pm 1,19$ & $10,040 \pm 0,004$ & $3,397 \pm 0,004$ & 0,065 & $8,23 \pm 0,19$ & $99,00 \pm 1,12$ & 1,13 & 6,427 & 1,04 \\
\hline
\end{tabular}

Keterangan :

a. Data masing-masing pengujian merupakan hasil purata dan standard deviation (SD)

b. Data uji kerapuhan, daya serap dan floating lag time merupakan hasil sekali pengujian

Hasil uji mutu fisik tablet menunjukkan bahwa tablet memenuhi persyaratan keseragaman bobot yang ditetapkan Farmakope Indonesia edisi III dan CV yang dihasilkan kurang dari 5\% menunjukkan bahwa variasi keseragaman bobot dalam setiap formula kecil. Keseragaman kandungan zat aktif dalam tiap tablet memenuhi persyaratan yang tercantum dalam USP 32 karena berada dalam rentang $90 \%$ dan $110 \%$ dari jumlah nifedipin yang tercantum pada etiket. Tablet yang terbentuk keras dan tidak rapuh dengan ukuran yang seragam.

Uji daya serap tablet bertujuan untuk mengetahui kecepatan penetrasi media kedalam tablet. Faktor yang mempengaruhi penetrasi media adalah porositas tablet yang tergantung pada kompresi dan kelembaban dari bahan yang dipakai.Gambar1. Menjelaskan contour plot pengaruh variasi kombinasi HPMC K15M, PVP K-30 dan Avicel PH 102 terhadap daya serap tablet. Berdasarkan hasil perhitungan menggunakan software Design Expert7.1.3, dihasilkan persamaan sebagai berikut:

$$
\begin{aligned}
\mathrm{Y}_{1}= & 0,032 \mathrm{X}_{\mathrm{A}}+0,097 \mathrm{X}_{\mathrm{B}}-1,89 \times 10^{-4} \mathrm{X}_{\mathrm{C}^{-}} \\
& 7,38 \times 10^{-4} \mathrm{X}_{\mathrm{A}} \mathrm{X}_{\mathrm{B}}+3,29 \times 10^{-4} \mathrm{X}_{\mathrm{A}} \mathrm{X}_{\mathrm{C}^{-}} \\
& 2,54 \times 10^{-4} \mathrm{X}_{\mathrm{B}} \mathrm{X}_{\mathrm{C}}
\end{aligned}
$$

$$
\begin{aligned}
\text { Keterangan: } \quad \mathrm{Y}_{1}=\text { daya serap tablet } \\
\mathrm{A}=\text { proporsi HPMC K15M } \\
\mathrm{B}=\text { proporsi PVP K-30 } \\
\mathrm{C}=\text { proporsi Avicel PH } 102
\end{aligned}
$$




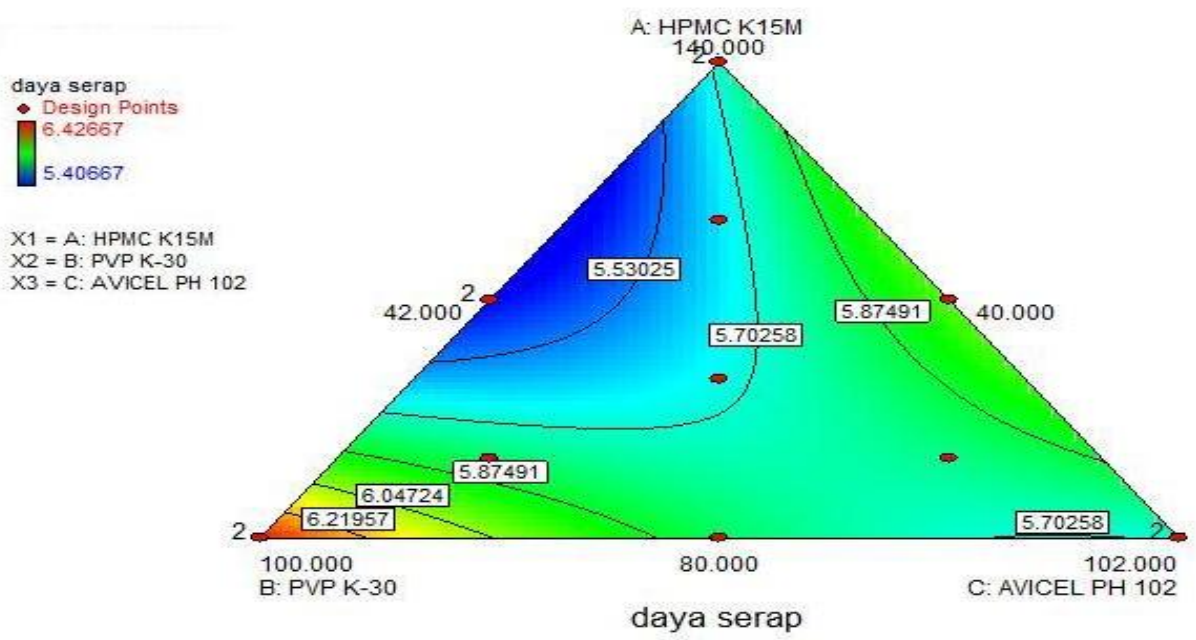

Gambar 1. Contour plot pengaruh variasi kombinasi HPMC K15M, PVP K-30 dan Avicel PH 102 terhadap daya serap tablet

HPMC K15M termasuk matriks hidrofilik dan bersifat higroskopis sehingga dapat meningkatkan daya serap. PVP K-30 dapat meningkatkan daya serap disebabkan karena PVP K-30 merupakan bahan yang mudah larut dalam air, sehingga setelah kontak dengan cairan, maka cairan akan cepat berpenetrasi dalam tablet, dan daya serapnya akan meningkat. Interaksi antara HPMC K15M - Avicel PH 102 berpengaruh menaikkan daya serap. HPMC K15M bersifat higroskopis mempermudah cairan berpenetrasi dalam tablet dan ketika Avicel PH 102 kontak dengan cairan, cairan akan segera memutus ikatan hidrogen yang mengikat partikel-partikel Avicel PH 102 sehingga memberi kontribusi dalam menaikkan daya serap.

Uji floating lag time bertujuan mengetahui kecepatan tablet untuk mengapung dalam media disolusi yang digunakan. Floating lag time yang cepat adalah tujuan dari pembuatan formula tablet floating.

Gambar 2. Menjelaskan contour plot pengaruh variasi kombinasi HPMC K15M, PVP K-30 dan Avicel PH 102 terhadap floating lag time.

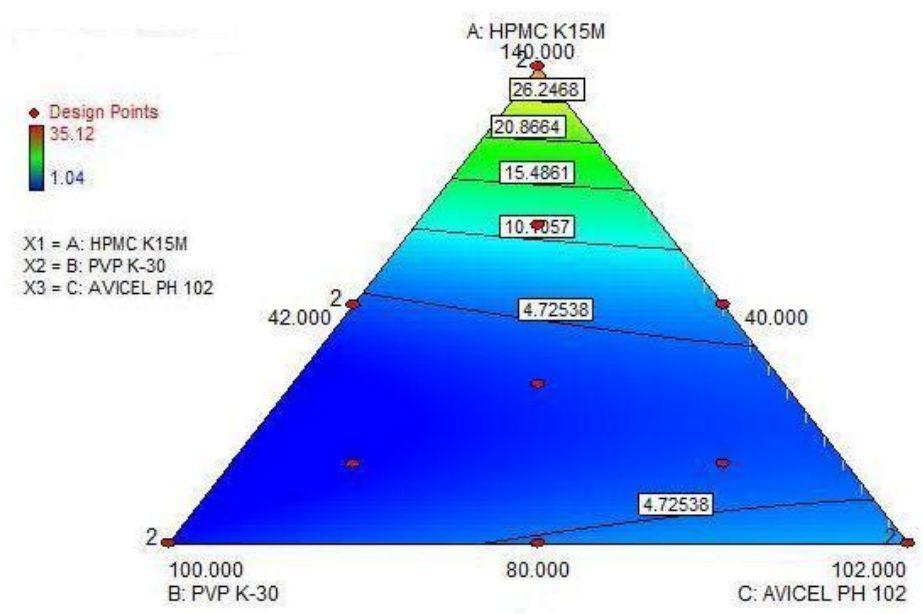

Gambar 2. Contour plot pengaruh variasi kombinasi HPMC K15M, PVP K-30 dan Avicel PH 102 terhadap floating lag time 
Berdasarkan hasil perhitungan menggunakan software Design Expert 7.1.3, dihasilkan persamaan sebagai berikut :

$\mathrm{Y}_{2}=1,055 \mathrm{X}_{\mathrm{A}}+0,463 \mathrm{X}_{\mathrm{B}}+0,563 \mathrm{X}_{\mathrm{C}}-$ $0,0139 \mathrm{X}_{A} \mathrm{X}_{\mathrm{B}}-0,014 \mathrm{X}_{\mathrm{A}} \mathrm{X}_{\mathrm{C}}+1,298 \times 10^{-3}$ $\mathrm{X}_{\mathrm{B}} \mathrm{X}_{\mathrm{C}}$

(13)

Keterangan: $\quad \mathrm{Y}_{2}=$ floating lag time

$\mathrm{A}=$ proporsi HPMC $\mathrm{K} 15 \mathrm{M}$

$\mathrm{B}=$ proporsi $\mathrm{PVP} \mathrm{K}-30$

$\mathrm{C}=$ proporsi Avicel $\mathrm{PH} 102$

Jumlah HPMC K15M yang semakin besar dapat meningkatkan floating lag time. Hal ini disebabkan karena HPMC K15M dengan konsentrasi yang besar akan membentuk lapisan gel yang lebih tebal yang akan menghambat penetrasi cairan dalam tablet, sehingga gas yang terbentuk tidak cukup kuat untuk segera mengapungkan tablet.

$\mathrm{C}_{360}$ adalah jumlah kumulatif nifedipin yang terlepas pada menit ke 360 dalam satuan persen. USP XXXII (2009) mensyaratkan bahwa tablet lepas lambat nifedipin, jumlah kumulatif obat yang terlepas pada menit ke 360 adalah antara $32 \%-54 \%$. Persyaratan ini untuk merancang sediaan yang dibuat dapat melepaskan zat aktif yang lebih lambat dan konstan.

Gambar 3. Menjelaskan contour plot pengaruh variasi kombinasi HPMC K15M, PVP K-30 dan Avicel PH 102 terhadap C360.

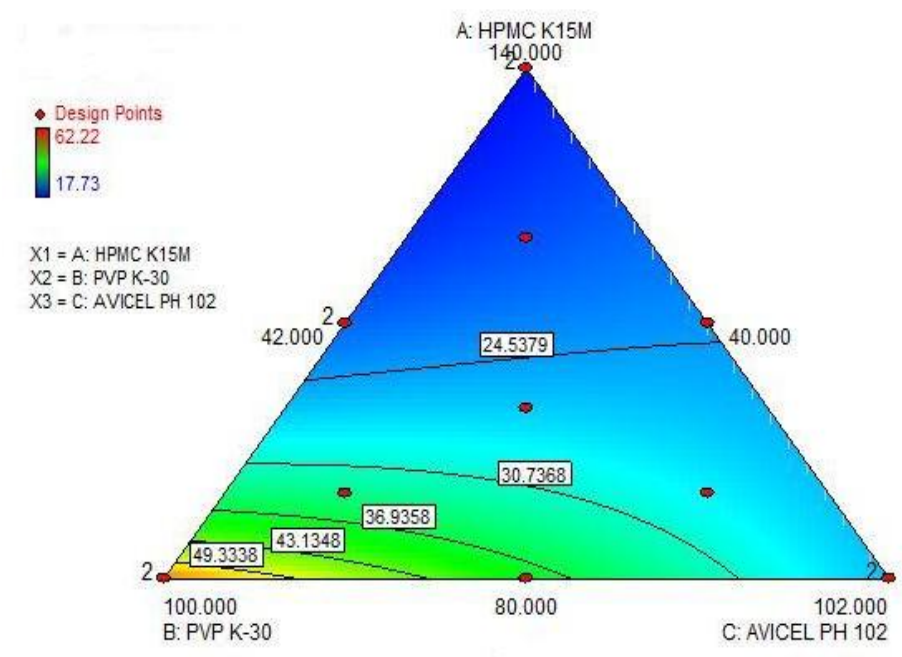

Gambar 3. Contour plot pengaruh variasi kombinasi HPMC K15M, PVP K-30 dan Avicel PH 102 terhadap $\mathrm{C}_{360}$

Berdasarkan hasil perhitungan menggunakan software Design Expert7.1.3, dihasilkan persamaan sebagai berikut :

$\mathrm{Y}_{3}=2,82 \times 10^{-4} \mathrm{X}_{\mathrm{A}}-8,55 \times 10^{-4} \mathrm{X}_{\mathrm{B}}+7,32 \mathrm{x}$

$10^{-4} \mathrm{X}_{\mathrm{C}}+1,00 \times 10^{-5} \mathrm{X}_{\mathrm{A}} \mathrm{X}_{\mathrm{B}}-5,65 \times 10^{-6}$

$\mathrm{X}_{\mathrm{A}} \mathrm{X}_{\mathrm{C}}-$

$2,62 \times 10^{-6} \mathrm{X}_{\mathrm{B}} \mathrm{X}_{\mathrm{C}}$

(14)

Keterangan: $\quad \mathrm{Y}_{3}=1 / \mathrm{C}_{360}$

$\mathrm{A}=$ proporsi HPMC $\mathrm{K} 15 \mathrm{M}$

$\mathrm{B}=$ proporsi $\mathrm{PVP} \mathrm{K}-30$

$\mathrm{C}=$ proporsi Avicel $\mathrm{PH} 102$
Hasil uji disolusi dapat juga diungkapkan dalam Efisiensi Disolusi (DE). DE adalah perbandingan luas dibawah kurva disolusi dengan luas segiempat seratus persen zat aktif dalam medium pada saat tertentu.

Gambar4. Menjelaskan contour plot pengaruh variasi kombinasi HPMC K15M, PVP K-30 dan Avicel PH 102 terhadap $\mathrm{DE}_{360}$. 


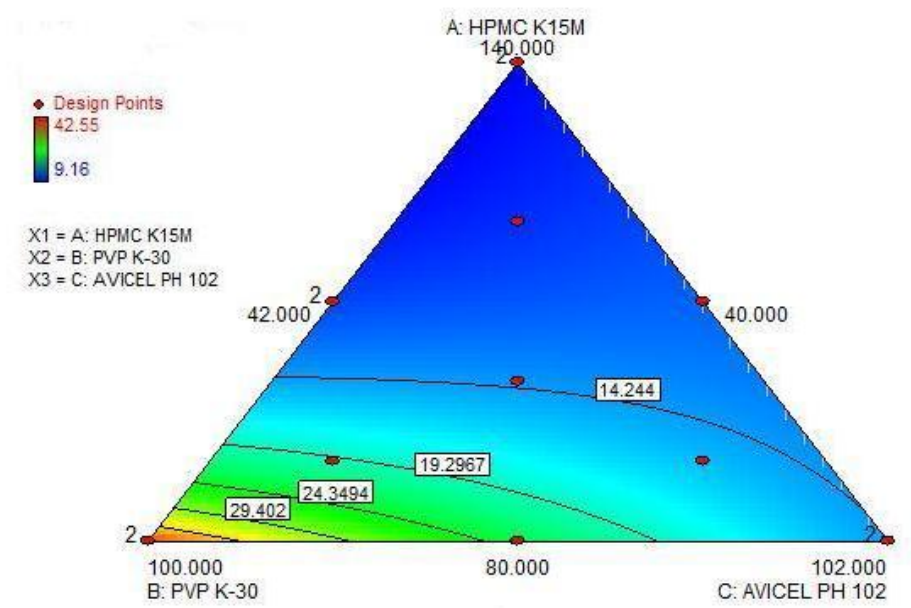

Gambar 4. Contour plot pengaruh variasi kombinasi HPMC K15M, PVP K-30 dan Avicel PH 102 terhadap $\mathrm{DE}_{360}$

Berdasarkan hasil perhitungan menggunakan software Design Expert7.1.3, dihasilkan persamaan sebagai berikut :

$$
\begin{aligned}
& \mathrm{Y}_{4}= 9,73 \times 10^{-4} \mathrm{X}_{\mathrm{A}}-4,55 \times 10^{-3} \mathrm{X}_{\mathrm{B}}+2,93 \times \\
& 10^{-3} \mathrm{X}_{\mathrm{C}}+5,93 \times 10^{-5} \mathrm{X}_{\mathrm{A}} \mathrm{X}_{\mathrm{B}}-1,27 \times 10^{-} \\
&{ }^{5} \mathrm{X}_{\mathrm{A}} \mathrm{X}_{\mathrm{C}}- \\
& 4,31 \times 10^{-6} \mathrm{X}_{\mathrm{B}} \mathrm{X}_{\mathrm{C}}
\end{aligned}
$$

Keterangan: $\quad \mathrm{Y}_{4}=1 / \sqrt{ } \mathrm{DE}_{360}$ $\mathrm{A}=$ proporsi HPMC $\mathrm{K} 15 \mathrm{M}$

$\mathrm{B}=$ proporsi PVP $\mathrm{K}-30$

$\mathrm{C}=$ proporsi Avicel $\mathrm{PH} 102$

HPMC K15M termasuk matriks hidrofilik dan bersifat higroskopis sehingga mempermudah penetrasi cairan dalam tablet dan berperan dalam menaikkan $\mathrm{DE}_{360}$. Jumlah Avicel PH 102 yang semakin besar dapat meningkatkan $\mathrm{DE}_{360}$.Hal ini disebabkan karena Avicel PH 102 bersifat kompresibel sehingga dapat menghasilkan tablet yang kompak, karena partikel-partikel Avicel PH 102 terikat bersama-sama oleh ikatan hidrogen. Ikatan hidrogen pada gugus hidrogen dalam molekul selulosa yang berdekatan bertanggung jawab terhadap kekuatan dan kekohesifan padatan (kompak). Kekuatan dan kekohesifan padatan Avicel PH 102 akan segera terdisintegrasi dengan cepat sehingga cairan segera berpenetrasi ke dalam tablet dan ikatan hidrogen langsung terputus (Siregar dan Wikarsa, 2010). Hal ini dapat meningkatkan penetrasi cairan kedalam tablet sehingga obat yang dilepaskan meningkat juga.

Interpretasi data disolusi dapat dilakukan dengan mengamati profil disolusi masing-masing formula. Profil disolusi dapat dibuat dengan memplotkan jumlah nifedipin yang terlepas (mg) dengan waktu. Profil disolusi tablet floating nifedipin disajikan pada gambar 1\& 2.Profil disolusi semua formula menunjukkan hubungan yang tidak linier sehingga tidak dapat digunakan untuk mengetahui mekanisme pelepasannya. 


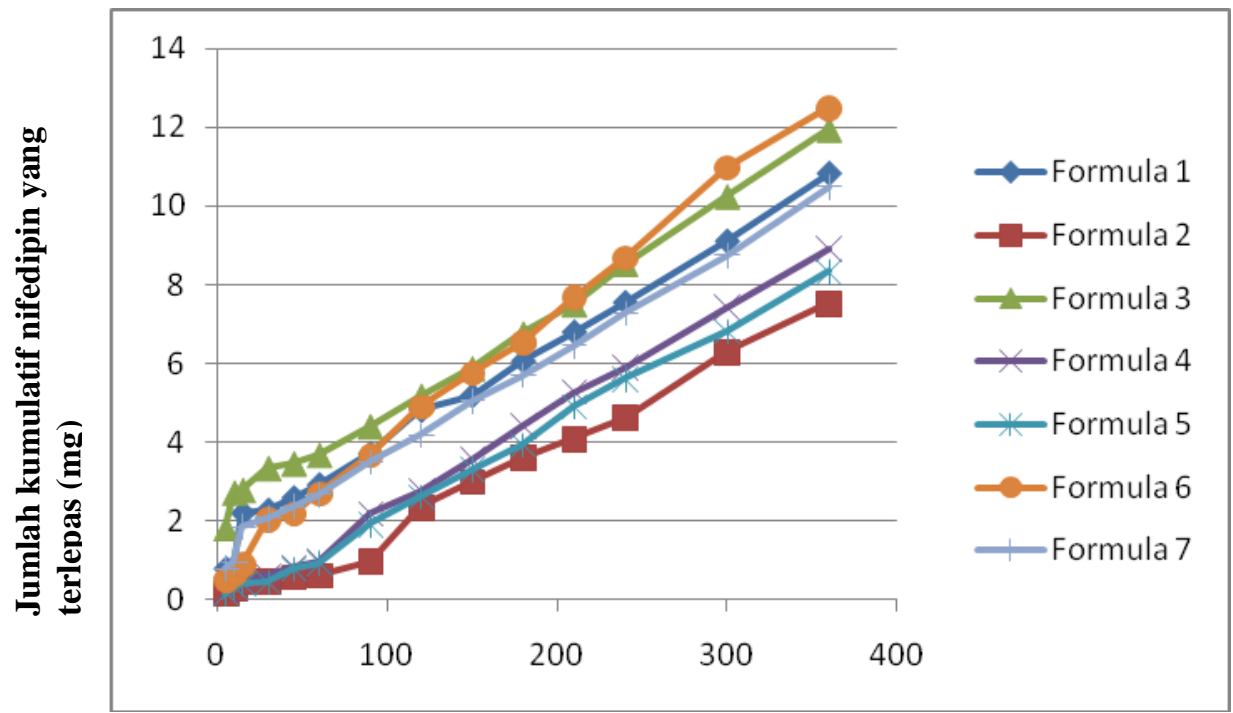

Gambar 5. Kurva hubungan jumlah nifedipin yang terlepas (mg) dengan waktu (menit) formula 1 sampai formula 7

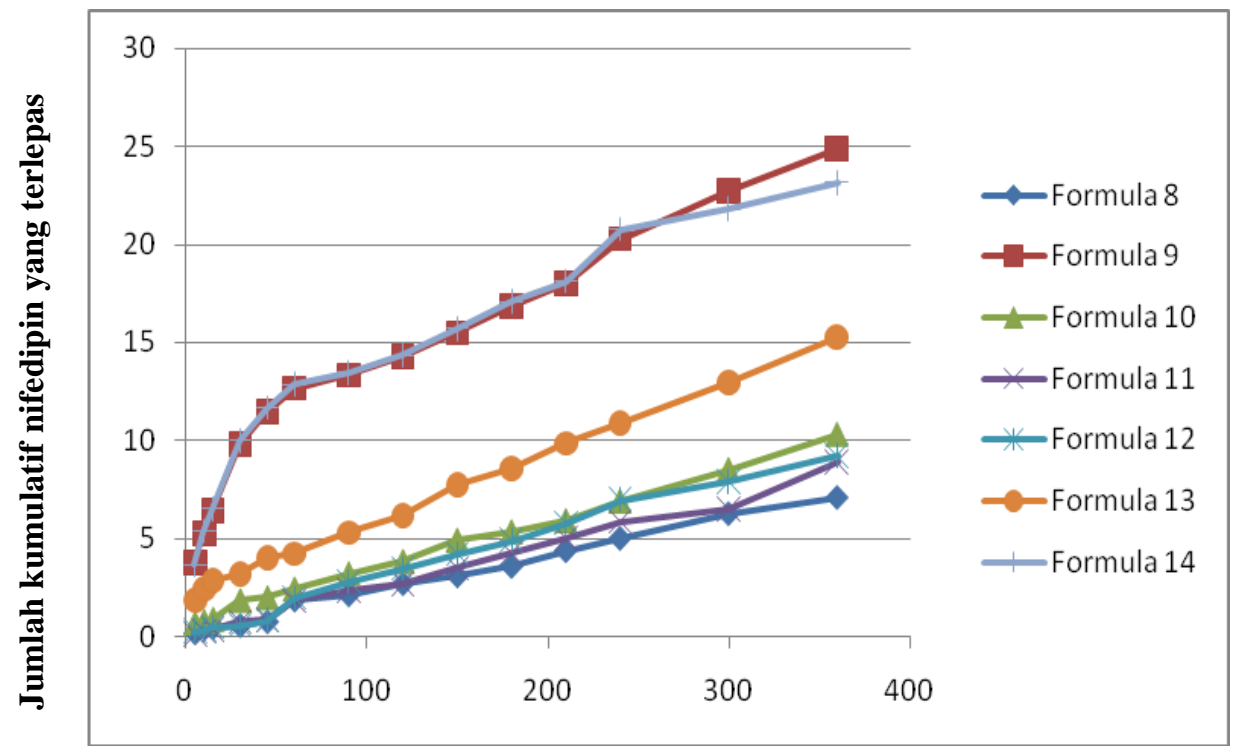

Gambar 6. Kurva hubungan jumlah nifedipin yang terlepas (mg) dengan waktu (menit) formula 8 sampai formula 14

Tahap awal dalam penentuan profil disolusi dalam penelitian ini adalah menghitung regresi nonlinear dengan 4 pendekatan mekanisme pelepasan. Mekanisme pelepasan yang digunakan adalah persamaan orde nol, persamaan orde pertama, persamaan Higuchi dan persamaan Korsmeyer Peppas. Tahap berikutnya setelah perhitungan regresi non linier dari 4 pendekatan mekanisme adalah curve fitting masing-masing formula. Curve fitting yang diperoleh dari semua formula dievaluasi Goodness of fit Qprediksi terhadap Qobservasi. Evaluasi goodness of fit ini digunakan untuk mendukung metode Curve fitting bahwa model kinetika disolusi berdasarkan pada curve fitting cocok dengan hasil observasi uji disolusi. 


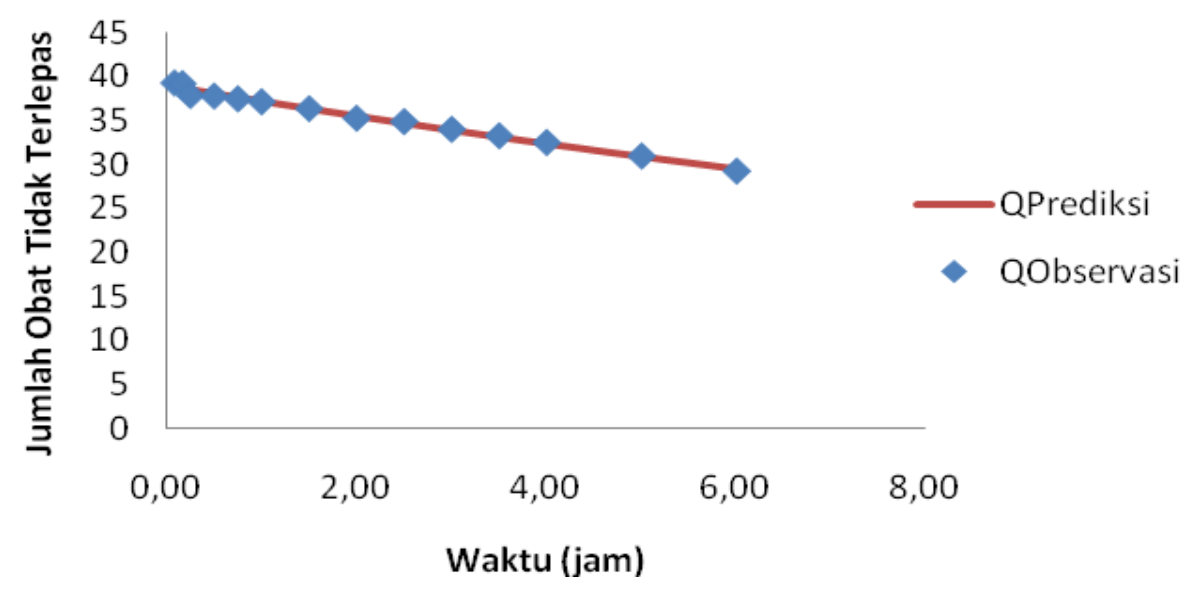

Gambar 7. Kurva curve fitting formula 1

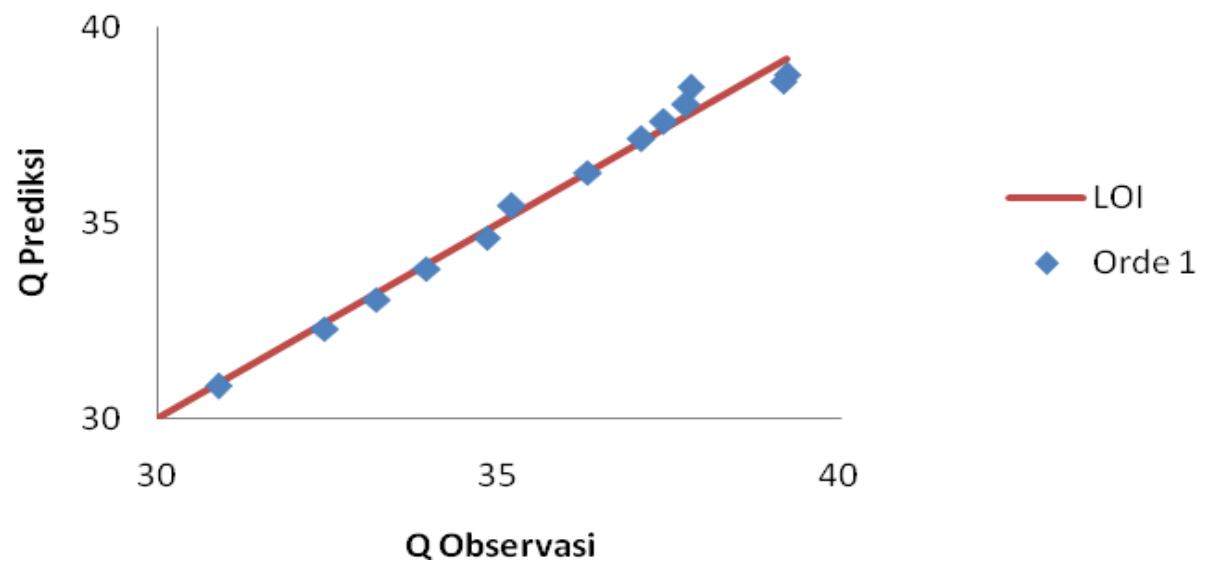

Gambar 8. Kurva goodness of fit formula 1

Mekanisme semua formula mengikuti persamaan orde 1 artinya pelepasan nifedipin dikontrol oleh mekanisme difusi. Jumlah obat dalam kompartemen donor akan semakin berkurang dengan bertambahnya waktu dan obat membutuhkan waktu yang lama untuk keluar dari matriks sehingga kecepatan difusinyasemakin lambat. Mekanisme difusi terjadi karena HPMC K15M ketika terhidrasi oleh cairan akan membentuk lapisan gel yang dapat dipertahankan dalam waktu tertentu dan sulit terkikis oleh cairan. Hal ini didukung juga dengan sifat PVP K-30 yang mudah larut dalam air semakin mempermudah penetrasi cairan dalam tablet.

Mekanisme pelepasan nifedipin dapat juga dijelaskan dengan nilai $\mathrm{n}$ yang diperoleh dari persamaan Korsmeyer Peppas, yakni nilai eksponensial difusi. Kriteria pelepasan obat berdasarkan geometri dari sampel (silinder) adalah: $\mathrm{n}=0,5$, mengikuti transport Fickian, $\quad 0,5<\mathrm{n}<1, \quad$ mengikuti transportanomalous, $\mathrm{n}=1$, mengikuti transport case II, $\mathrm{n}>1$, mengikuti transportsuper case II (Costa dan Lobo, 2001).

Formula 9 dan 14 mempunyai nilai $\mathrm{n}$ $<0,5$ berarti karakteristik pelepasan nifedipin mengikuti mekanisme transportFickian yang menggambarkan bahwa kecepatan pelepasan obat dapat dipengaruhi oleh koefisien difusi, ketebalan membran difusi dan volume media disolusi (Costa dan Lobo, 2001). Pelepasan obat melalui mekanisme difusi dapat dijelaskan bahwa jumlah obat akan berkurang 
dengan bertambahnya waktu, sehingga terjadi penurunan kecepatan obat, dan pelepasan obat tidak dapat dipertahankan berlangsung dengan konstan. Formula 1, 3, 6, 7, 8, 10, 11, 12, 13 mempunyai nilai $\mathrm{n}$ antara 0,5 dan 1 yang berarti karakteristik pelepasan nifedipin mengikuti mekanisme transport anomalous, yang mana kecepatan difusi dan relaksasi polimer adalah sebanding.Harga $\mathrm{n}$ diatas juga mengindikasikan bahwa pelepasan obat dikontrol lebih dari satu proses yaitu difusi dan erosi. Difusi terjadi ketika HPMC K15M kontak dengan cairan akan mengembang membentuk lapisan gel, lapisan gel inilah yang mengatur pelepasan obat melalui mekanisme erosi. Formula 2, 4, 5 mempunyai $\mathrm{n}>1$ yang berarti karakteristik pelepasan nifedipin mengikuti mekanisme super case II. Pada sistem ini, difusi air melewati lapisan yang baru mengembang berlangsung dengan cepat dibandingkan dengan kecepatan mengembang dari polimer, sehingga penetrasi air dikontrol oleh relaksasi polimer.

Langkah awal untuk menentukan daerah dengan sifat tablet yang optimum adalah dengan menentukan parameter kritisnya. Parameter yang digunakan untuk menentukan formula optimum adalah daya serap tablet, floating lag time, $\mathrm{C}_{360}$ dan $\mathrm{DE}_{360}$. Keempat parameter dianalisis menggunakan software Desain Expert 7.1.3 untuk menentukan formula optimum. Superimposed contour plot parameter optimasi dapat dilihat pada Gambar 9.

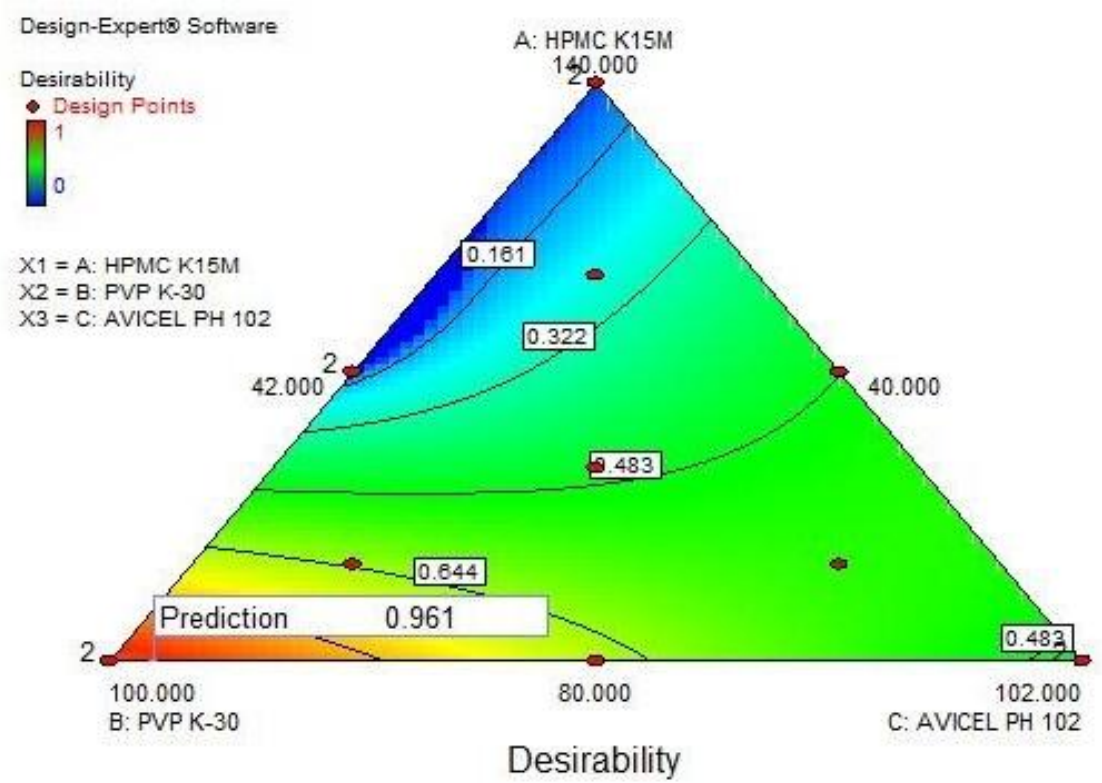

Gambar 9. Superimposed contour plot parameter optimasi

Formula optimum diperoleh dengan menentukan target yang diinginkan untuk masing-masing parameter. Daya serap dipilih target yang maksimum,floating lag time dipilih target yang minimum, $\mathrm{C}_{360}$ dipilih target pada angka 54,DE 360 target pada angka 40.

Hasil optimasi formula tablet floating nifedipin dapat dilihat pada Tabel 9berdasarkan pendekatan desirability total maksimum 0,961. Prediksi tiap parameter optimasi daya serap $6,3 \mathrm{mg} / \mathrm{menit}$; floating lag time 2,14 menit, $\mathrm{DE}_{360} 38 \%$ dan $\mathrm{C}_{360} 54 \%$.

Hasil pengujian parameter optimasi dilakukan dengan membandingkan parameter optimasi antara hasil prediksi yang dihasilkan oleh software dengan hasil observasi dari formula optimum. Hasilnya sebagaimana dalam Tabel 7. 
Tabel 5. Komposisi Formula Optimum Hasil Analisis dengan Perangkat Lunak Design Expert

\begin{tabular}{lc}
\hline \multicolumn{1}{c}{ Nama Bahan } & Bobot (mg) \\
\hline Nifedipin & 40 \\
HPMC K15M & 80 \\
PVP K-30 & 97 \\
Avicel PH 102 & 45 \\
Asam sitrat & 13,8 \\
Natrium bikarbonat & 18,2 \\
Magnesium stearat & 3 \\
Talk & 3 \\
\hline
\end{tabular}

Tabel 6. Hasil Uji Mutu Fisik Massa Tablet Dan Tablet Formula Optimum

\begin{tabular}{|c|c|}
\hline $\begin{array}{l}\text { Uji mutu fisik massa tablet \& } \\
\text { tablet }\end{array}$ & $\begin{array}{l}\text { Hasil uji mutu fisik massa tablet \& } \\
\text { tablet }\end{array}$ \\
\hline Kecepatan alir (g/detik) & $11,88 \pm 0,45$ \\
\hline Sudut diam $\left(^{\circ}\right)$ & $28,35 \pm 0,39$ \\
\hline Kompresibilitas (\%) & $20,67 \pm 0,39$ \\
\hline Bobot tablet (mg) & $0,299 \pm 0,000$ \\
\hline Kerapuhan (\%) & $0,08 \pm 0,02$ \\
\hline Kekerasan $(\mathrm{Kg})$ & $8,64 \pm 0,17$ \\
\hline Diameter (mm) & $10,00 \pm 0,000$ \\
\hline Ketebalan $(\mathrm{mm})$ & $3,32 \pm 0,05$ \\
\hline Daya serap (mg/detik) & $6,34 \pm 0,04$ \\
\hline Floating lag time(menit) & $2,11 \pm 0,01$ \\
\hline Durasi floating(jam) & $>24$ \\
\hline Keseragaman kandungan (\%) & $99,60 \pm 0,18$ \\
\hline
\end{tabular}

Keterangan :

Data masing-masing pengujian merupakan hasil purata dan standard deviation (SD)

Profil disolusi dapat dibuat dengan memplotkan jumlah nifedipin yang terlepas (mg) dengan waktu. Profil disolusi formula optimum tablet floating nifedipin disajikan pada Gambar 10. Profil disolusi formula optimum menunjukkan hubungan yang tidak linier, sehingga tidak dapat digunakan untuk mengetahui mekanisme pelepasannya. Mekanisme pelepasan dapat dijelaskan dengan pendekatan non linier karena lebih tepat dalam menggambarkan pelepasan obat dalam disolusi.

Tabel 7. Hasil Pengujian Parameter Optimasi

\begin{tabular}{lllll}
\hline Parameter optimasi & Prediksi & Observasi & Kesimpulan & Nilai P \\
\hline Daya serap (mg/menit) & 6,3 & $6,34 \pm 0,049$ & Tidak berbeda signifikan & 0,293 \\
Floating lag time (menit) & 2.14 & $2.11 \pm 0,01$ & Berbeda signifikan & 0,035 \\
C $_{360}(\%)$ & 54 & $53,24 \pm 1,325$ & Tidak berbeda signifikan & 0,425 \\
DE $_{360}(\%)$ & 38 & $39,39 \pm 0,594$ & Tidak berbeda signifikan & 0,056 \\
\hline
\end{tabular}




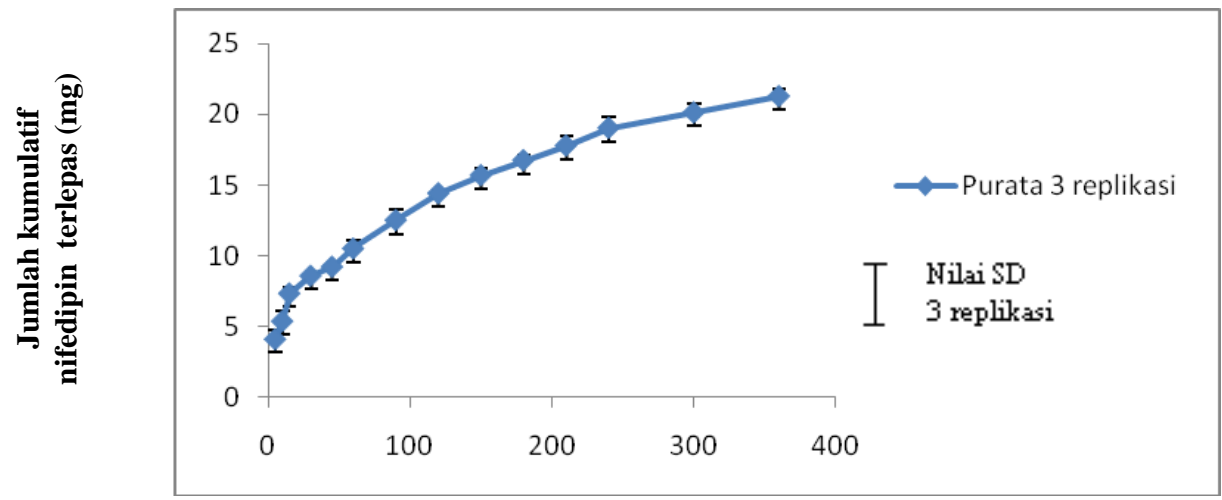

Waktu (menit)

Gambar 10. Kurva hubungan jumlah nifedipin yang terlepas (mg) dengan waktu (menit) formula optimum (data disajikan sebagai purata \pm SD)

Mekanisme pelepasan formula optimum mengikuti persamaan orde 1 . Hal ini dapat dijelaskan dengan adanya kesesuaian

kurva yang terbentuk antara hasil prediksi solver dan hasil percobaan disajikan pada Gambar 11.

ORDE PERT AMA

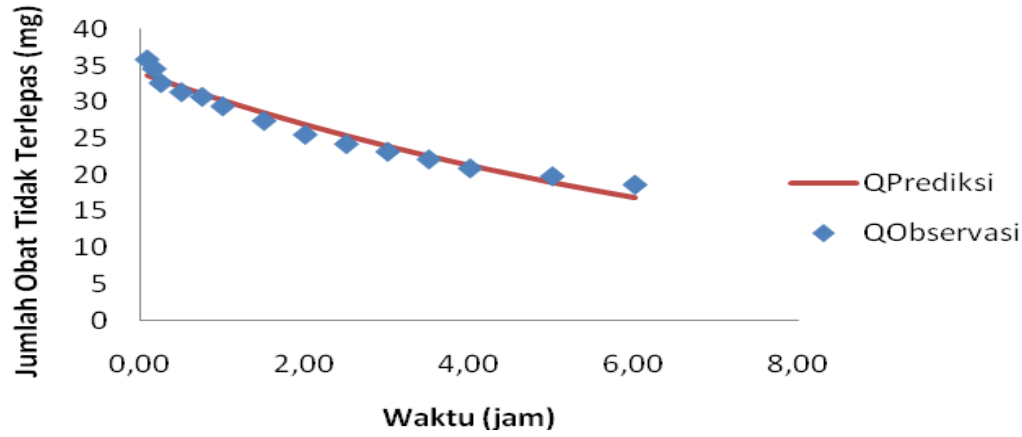

Gambar 11. Curve Fittingformula optimum

Curve fitting yang diperoleh dievaluasi goodness of fituntuk mendukung bahwa mekanisme pelepasan pada curve fittingsesuai dengan hasil observasi. Kurva goodness of fitformula optimum yangdiperoleh dapat dilihat pada Gambar 12.

\section{ORDE PERTAMA}

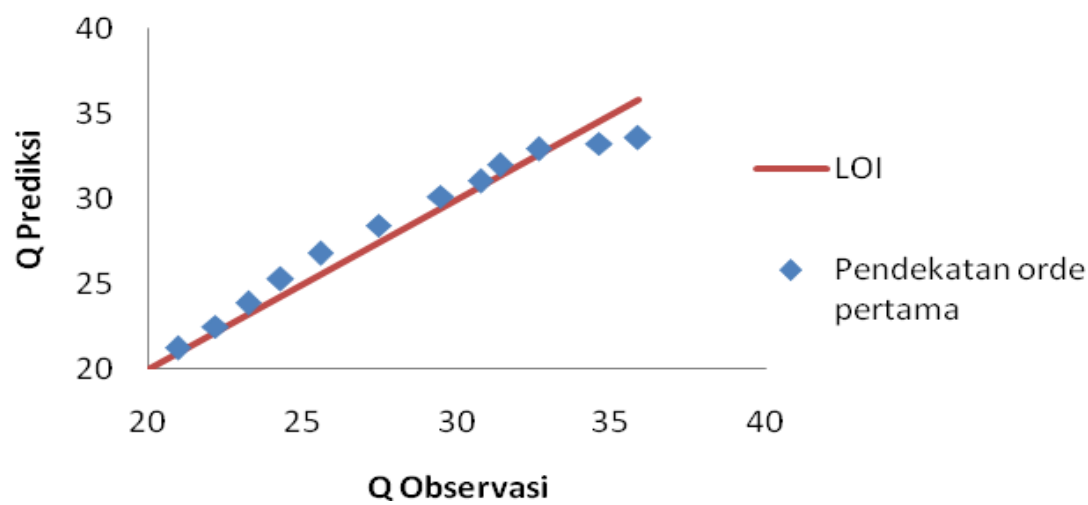

Gambar 12. Goodness of fitformula optimum 
Mekanisme formula optimum mengikuti persamaan orde 1, artinya pelepasan nifedipin dikontrol oleh mekanisme difusi. Jumlah obat dalam kompartemen donor akan semakin berkurang dengan bertambahnya waktu, dan obat membutuhkan waktu yang lama untuk keluar dari matriks, sehingga kecepatan difusinya semakin lambat. Mekanisme difusi terjadi karena HPMC K15M ketika terhidrasi oleh cairan akan membentuk lapisan gel yang dapat dipertahankan dalam waktu tertentu dan sulit terkikis oleh cairan. Hal ini didukung juga dengan sifat PVP K-30 yang mudah larut dalam air sehingga semakin mempermudah penetrasi cairan dalam tablet.

Berdasarkan hasil uji durasi floating, formula optimum tablet floating nifedipin diprediksi dapat bertahan dalam lambung selama 24 jam sesuai dengan yang diharapkan. Waktu tinggal obat dalam lambung yang panjang dapat meningkatkan bioavaibilitas dan mengurangi obat yang terbuang sia-sia. Jumlah kumulatif nifedipin yang terlepas pada menit ke 360 sebesar $53 \%$ menunjukkan bahwa proses disolusi mencapai tingkat maksimal sehingga obat yang terabsorpsi juga maksimal sehingga memberikan efek terapi yang maksimal.

\section{KESIMPULAN DAN SARAN}

\section{A. Kesimpulan}

Berdasarkan hasil penelitian yang telah dilakukan dapat diambil kesimpulan sebagai berikut:

1. HPMC K15M pada konsentrasi paling tinggi berpengaruh pada pelepasan nifedipin paling kecil, PVP K-30 pada konsentrasi paling tinggi berpengaruh pada pelepasan nifedipin paling besar, sedangkan Avicel PH 102 pada konsentrasi paling tinggi berpengaruh kecil terhadap penurunan floating lag time tablet floating nifedipin.

2. Proporsi formula tablet floating nifedipin yang optimum adalah HPMC K15M 80 mg, PVP K-30,97 mg dan Avicel PH 102,45 mg. Formula optimum ini memberikan hasil pengujian daya serap, $\mathrm{C}_{360}$ dan $\mathrm{DE}_{360}$ yang tidak berbeda signifikan terhadap hasil prediksi openstat.

\section{B. Saran}

Perlu dilakukan penelitian lebih lanjut dengan optimasi komponen effervescent sehingga diperoleh proporsi yang tepat dalam formula tablet floating nifedipin.

\section{DAFTAR PUSTAKA}

Agoes, G. 2008, Sistem penghantaran Obat pelepasan Terkendali, Institut Teknologi bandung, Bandung, 75 76.

Anonim, 1994, International Conference on Harmonisation of Technical Requirements for Registration of Pharmaceutical for Human Use, Validation of Analytical Procedure: Text and Methodology Q2(R1), 1-13.

Anonim, 1995, Farmakope Indonesia, Edisi IV, Departemen Kesehatan Republik Indonesia, Jakarta, 611 - 613.

Anonim, 2009, The United States Pharmacopeia, $32^{\text {rd }}$ edition, The United States Pharmacoprial Convention Inc, Rockville, 104 - 107.

Bolton, S. and Bon, C. 2004, Pharmaceutical Statistics Practical and Clinical Applications, $4^{\text {th }}$ Ed., Marcel Dekker, Inc., New York, 610 - 619.

Cahyani, I.M. 2012, Optimasi Formula Tablet Floating

GastroretentiveNifedipinMenggunaka $\mathrm{n}$ Metode Effervescent dengan Matriks HPMC K100M dan Etilselulosa, Tesis. Yogyakarta: Universitas Gadjah Mada Yogyakarta.

Chander, S.B., Shiressh, K.R. and Nagendra, B.B. 2010, Preparation and Evaluation of Gastroretentive Floating Tablets of Ketokonazol, International Journal of Pharmaceutical Research \& Development Vol.2 Issue 9.

Collet, J. and Moreton, C. 2002, 'Modified Release Per Oral Dosage Form'.in Aulton, M.E, (ed).Pharmaceutics The Science of Dosage Form Design, 2nd Edition, Churchill Livingstone, Edinburg, 483-494.

Costa, P. and Lobo, J.M.S. 2001, Modelling and Comparison of Dissolution Profiles, European Journal of 
Pharmacentical Sciences 13(2001)123133.

Daharwal, S.J. 2007, Gastro-Retentive Drugs : A Novel Approach Towards Floating Therapy, Pharmainfonet Vol.(5) Issue 1.

Dixit, N. 2011, Floating Drug Delivery System, Journal of Current Pharmaceutical Research, 7(1) : 6-20.

Fudholi, A. 2013, Disolusi dan Pelepasan Obat in Vitro, Pustaka Pelajar, Yogyakarta, $137-147$.

Gandjar, I.G. dan Rohman, A. 2007, Kimia Farmasi Analisis, Pustaka Pelajar, Yogyakarta, 465 - 469.

Garg, R. and Gupta, G.D. 2008, Progress in Controlled Gastroretentive Delivery System, Tropical Journal of Pharmacentical Research: 7(3): 10551066.

Garg, S. and Sharma, S. 2003, Gastroretentive Drug Delivery Systems. Phamatch, 20: 160-166.

Hardenia, S.S., Jain, A., Patel, R. and Kaushal, A. 2011, Floating Drug Delivery System: A Review, Asian Journal of Pharmacy and Life Science 1(3) : 42-51.

Hardjono, S. 2000, Hubungan Struktur Aktivitas Obat Kardiovaskular , dalam Siswandono \& Soekardjo, B, (Ed). Kimia Medisinal, Airlangga University Press, Surabaya, 340.

Kumar, K.P.S., Bhowmik, D., Chiranjib, Chandra, M. and Tripathi, K.K. 2010, Innovation in Sustained Release drug Delivery System and Its market Opportunities, Journal of Chemical and Pharmacentical Research 2(1):349-360.

Lachman, L., Lieberman, H. A. and Kanig, J.L. 2008, Teori dan Praktek Farmasi Industri edisi 3 Jilid 2, diterjemahkan dari bahasa Inggris oleh Suyatmi, S. Universitas Indonesia Press, Jakarta, 893 - 904.

Lalitha, Y. and Lakshmi, P.K. 2011, Enhancement of Dissolution of Nifedipin by Surface Solid Dispersion Technique, International Journal of Pharmacentical Sciences 3(3): 41-46.

Mahale, G.S. and Derle, N.D. 2012, Floating Drug Delivery System : A Novel
Approach, Journal of Pharmacentical and

Scientific Innovation, 1(4): 1-6.

Miller, J.,C. and Miller, J.,N. 2005, Statistics for Analytical Chemistry, $2^{\text {nd }}$ edition, Jhon Wiley Sons, New York, pp 109-120.

Moffat, A.C., Osselton, M.D. and Widdop, B. 2011, Clarke's Analysis of Drugs and Poisons. 4th edition, Pharmaceutical Press, London, 1777 - 1778.

Mohammed, M. and Ali, S. 2011, Development and In Vitro Evaluation of Gastroretentive FloatingTablets of Famotidin, International of Journal Pharmaceutical and Research Vol.(5) Issue 4.

Musnina, W.O.S. 2012, Optimasi Formula Tablet Nifedipin Gelling FloatingGastroretentive Menggunakan Matriks HPMC K4M, Carbopol 940 dan Eudragit RSPO, Tesis. Yogyakarta: Universitas Gadjah Mada Yogyakarta.

Nayak, A.K., Maji, R. and Das, B. 2010, Gastroretentive Drug Delivery System : A Review, Asian Journal of Pharmaceutical and Clinical Research Vol.3 Issue 1.

Nurjayanti, I. 2008, Optimasi Formula Tablet Lepas Lambat Nifedipin dengan Sistem Matrik Hidroksipropil Metilselulosa, Etil Selulosa dan Laktosa, Tesis, Universitas Gadjah Mada, Yogyakarta.

Padmavathy, J., Saravanan, D. and Rajesh, D. 2011, Formulation and Evaluation of Ofloxacin Floating Tablet Using HPMC, International Journal of Pharmacy and Pharmaceutical Sciences Vol. 3, Issue 1, 170 - 173.

Radhakrishna, M., Parthiban, K.G., Ramarao, N., Deepika, N.S. and Abhishek, P. 2012, Formulation and Evaluation of Floating Drug Delivery System of Amoxycillin Trihydrate, International Research Journal of Pharmacy 3 (8).

Reza, M.S., Quadir, M.A. and Haider, S.S. 2003, Comparative Evaluation of Plastic, Hidrophobic and Hidrophilic Polimers as Matrices for Controlled Release Drug Delivery, Journal of Pharmacy and Pharmaceutical Sciences 6(2):274-291. 
Rhodes, 1992, Nifedipine-containing Pharmaceutical Composition and Process for the Preparation thereof, Ethical Pharmaceutical, Ltd, Vol. 5.

Rowe, C.R., Sheske, P. and Quinn, M.E 2009, Handbook of Pharmaceutical Excipient, $6^{\text {th }}$ edition, Pharmaceutical Press and American Pharmacist Association, London and Chicago, 134 - 136, 181 - 183, $404-407,629-661,728$ 730.

Saigal, N., Baboota, S., Ahuja, A. and Ali, J. 2009, Microcrystalline Cellulose as A Versatile Excipient in Drug Shaikh, K.N.,Payghan, S.A. and Desouza, J.I. 2011, Formulation of Gastroretentive Drug Delivery System (Floating Tablets) of Nifedipine, International Journal of Pharmacy and Biological Sciences, 1(2):1-8

Shargel, L., Wu-Pong, S. and Yu, A.B.C. 2004, Applied Biopharmacentics \& Pharmacokinetics, $5^{\text {th }}$ Ed., The Mc GrawHill Companies.Inc. New York, 169 180.

Shim, S.,C., Pae, A.,N. and Lee, Y.,J. 1988, Mechanistic Study on The Photochemical Degradation of Nifedipine, Bulletin of The Korean Society, 9 (5), 1-4.

Singh, L.P., Rajesh, K.S., Umalkar, D.G., Chauhan, V., Rana, V. and Vasava, K.S. 2011, Floating Effervescent Tablet : A Review, Jounal Pharmacy and Biological Sciences 5(11).

Sinko, P.J. and Singh, H., (ed), 2011, Martin's Physical Pharmacy and Pharmacentical Sciences Physical Chemical and Biopharmaceutical Principles in the Pharmacentical Sciences, 6th Ed. Lippincott Williams \& Wilkins a
Research, Jounal of Young Pharmacist (1): 6-12.

Sandeep, K.G., Sathish, D. and Madhusudan, R.Y. 2012, Formulation and Evaluation of Gastroretentive Floating Tablet of Cefuroxime Axetil, International Journal of Research Pharmacentical \& Biomedical Sciences Vol.3 (1): 1-3

Shah S.H., Patel, J.K. and Patel, N.V. 2009, Stomach Specific Floating Drug Delivery System: A Review, International Jounal of PharmTech., 3: 623-633.

Wolters Kluwer Bussines, Philadelphia, 300 - 318.

Siregar, C.J.P. dan Wikarsa, S. 2010, Teknologi

Farmasi Sediaan Tablet Dasar-dasar Praktis, Buku Kedokteran EGC, Jakarta, 423 - 426.

Sreekanth, S.K., Palanichany, S., Sekharan, T.R., Thirapathi, A. and Thanga. 2010, Formulaion and Evaluation Studies of Floating Matriks Tablet of Nifedipin, International Jounal of Pharmacy and Biological Sciences 1(2):1-8.

Sweetman, S.C. 2009, Martindale The Complete Drug Reference, Vol. I, 36 ${ }^{\text {th }}$ Ed., Pharmaceutical Press, London, 1350 1357.

Voigt, R. 1994, Buku Pelajaran Teknologi Farmasi. Edisi Kelima, diterjemahkan dari bahasa Inggris Oleh Noerono, S. Gadjah Mada University Press, Yogyakarta, 341 361.

Wicaksono, Y. 2006, Pengembangan Sediaan Lepas Lambat $\mathrm{Na}$ Diklofenak Berbasis Matrik Etilselulosa - PVP K-30, Jurnal Ilmu Dasar, 7(2):170176 